\title{
Design of Standard Operational Procedures for Commercialization of BPPT's Food Technology Products in Incubation Programs
}

\author{
Intan Satwika Putri ${ }^{1}$, Adithya Sudiarno ${ }^{2}$ and Sri Gunani Partiwi ${ }^{3}$ \\ 1, Balai Teknologi, Badan Pengkajian dan Penerapan Teknologi, Tangerang Selatan, Indonesia \\ ${ }^{2,3}$ Industrial Engineering, Faculty of Industrial Technology, Institut Teknologi Sepuluh Nopember, \\ Indonesia
}

satwikaintan@gmail.com¹, adithya.sudiarno@gmail.com²

\begin{abstract}
Business incubation is one of the technology transfer schemes that can be carried out by government institutions in Indonesia such as the Badan Pengkajian dan Penerapan Teknologi (BPPT) so that their findings can be produced and commercialized to be utilized by the public. One of the business incubation service providers in Indonesia is the Balai Inkubator Teknologi (BIT). BIT is a BPPT work unit that provides incubation services for incubation participants (tenants). Based on previous research, the performance of BIT has not been optimal based on the survival rate of tenants who graduated only $29 \%$, which was mentioned due to the lack of standardized references for facilitators in assisting tenants. To improve it, in this study we will make a design model for Standard Operational Procedure (SOP) for BIT market access which can be a good reference. In developing the model, various approaches are used, namely lean startup, business model canvas, blue ocean strategy, marketing Funnel, analytical hierarchy process (AHP), etc. In order for the model to be valid and reliable, in this study three food products were made observations, namely cassava rice, spirulina sago noodles, and black garlic (BG).
\end{abstract}

Keywords: Incubation, SOP, BPPT, Lean Startup, Business Model Canvas, Blue Ocean Strategy, Marketing Channel, AHP

\section{Introduction}

One indicator that can be used to evaluate the level of innovation in a country is the number of patents. In order to increase the number of patents, the Government of Indonesia has made patents as one of the KPI of the institutions especially education and research institutions. And BPPT one of it. In the process of evaluating technology, BPPT shows its seriousness in carrying out its duties, as evidenced by the many patents held, namely 172 patents. Of the several patents, only a small portion can be used by the public. This shows that the findings or inventions cannot all be called innovations because innovation according to [1] is a form of success of inventions that can be utilized by the community through the process of commercialization and production.

In commercializing its technological products, BPPT has regulatory constraints so that state institutions cannot conduct business activities directly. Therefore, it is necessary to transfer the technology to other parties as stipulated in Government Regulations (PP No. 20 of 2005 article 
2). Commercialization activities can develop well and sustainably if the parties that accept the technology transfer process are professional business people. In the implementation of business development activities as a result of technology transfer can be done with various schemes, one of which is through an incubation program. According to PP No. 27 of 2013 the definition of incubation is the process given to incubation participants (tenants) in the form of assistance for business development. It is well known that the Incubation activity consists of 3 stages, namely pre-incubation, incubation and post-incubation. While for more detailed activities there are no concessions agreed globally so that each business incubator in practice will have a different curriculum. Differences can occur because the problems faced by each tenant in developing a business are unique.

Through the incubation program, BPPT in its organizational structure has a work unit of Technology Incubator (BIT) that functions as a business incubator. BIT was formally established in 2001 with the main function as a work unit for the commercialization of technology, especially the results of the BPPT study. As a business incubator, BIT focuses on technology in accordance with the functions of BPPT as the parent institution. In carrying out incubation services, the performance of the given BIT can be said to be not optimal because the survival rate of tenants who graduate is only $29 \%$ with $46.67 \%$ experiencing obstacles at the market access stage[2] The problem regarding the unequal assistance by the facilitator according to Cakrasiwi (2015) has an important role in the low success rate of BIT in delivering tenants to develop their business at a further stage. In order to improve the performance of BIT, this study will create a design for the market access SOP model that can be used as a reference to improve the existing SOP model that is too general. The proposed SOP improvement model to be reviewed is to make reference to market access for each technology field as shown in figure 1.

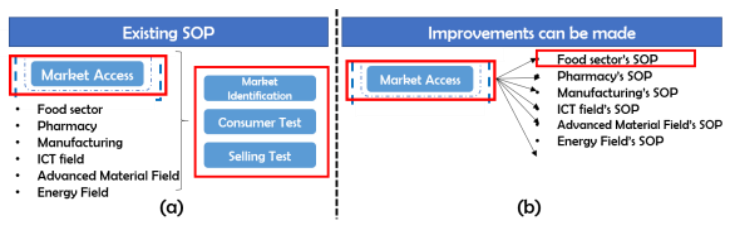

Fig. 1. Existing SOP (a) and proposal SOP (b)

In commercialization many approaches can be used where one of them is the concept of The Lean Startup developed by [3] Ries With his experience as a businessman and mentor of startup companies, Ries sees that there are inefficiencies in the theory of business development so Ries [3] took the initiative to develop a method written in the book The Lean Startup. The Lean Startup can be called a revolutionary business concept because it is considered an efficient method and is suitable for startups [4].

Many positive reviews have been expressed by various business experts regarding the positive benefits of the concept of The Lean Startup, so that BIT in 2014 tried to adopt it to be applied in incubation activities. BIT seeks to translate concepts in its business process activities from Pre-Incubation to Incubation in the business validation phase. The application of Lean Startup concept in Indonesia according to [5] Nirwan requires various adjustments related to regulatory differences, market conditions, and startup capabilities compared to applications in the United States as the country where this method was developed.

In this study to compile a reliable reference model of activities, in this study three observations will be used. And three BPPT inventions that can be observed are Cassava Rice, Spirulina Sago Noodles, and Black Garlic (BG). 


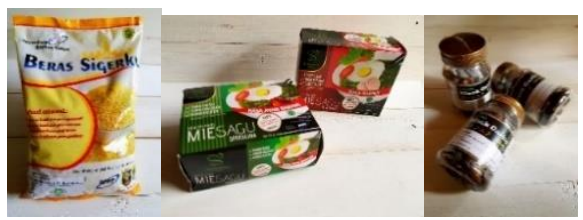

Fig. 2. Cassava Rice, Spirulina Sago Noodles and Black Garlic (BG)

\section{Lean Startup for Incubation Curriculum}

In developing the SOP model, it starts with conducting a literature study of various theories. With a variety of positive reviews, since 2014 BIT has adopted this concept, therefore in this study Lean Startup is the main method used. In its application, [3] Ries states that good business is a business that continues to be developed, measured, and studied for all ideas, products, and data obtained, therefore in business incubation activities the validation process should not only be done at the beginning of the idea. the idea of business development but at each stage so that the market access stage needs to be validated on the planned business model with the aim of verifying. The concept of the business model used in this study is the canvas model business (BMC) developed by [6]Ostewalder and Pigneur because it is easily made and understood even though it is not a marketing and efficient expert, which can be presented on a piece of paper. $\mathrm{BMC}$ has been proven to be used in various fields of business, the only difference is which blocks will be the starting point. In his book, to facilitate the preparation of business models, Ostewalder and Pigneur divided 4+1 epicenter groups based on inventive, offer driven, customer driven, finance driven, and multiple-epicenter driven resources. Of the five concepts that best fit the BPPT invention, which is an innovation product, is an offer-driven group so the preparation of the BMC will begin by describing the value propositions offered. In this study also tried to propose the BMC compilation model to be adapted to the conditions of the products produced by tenants which in its preparation were enhanced by adopting a blue ocean strategy (BOS) strategy and marketing funnel.

\section{Methodology}

The study of the development of market access SOP models is carried out in four stages illustrated in the following figure:

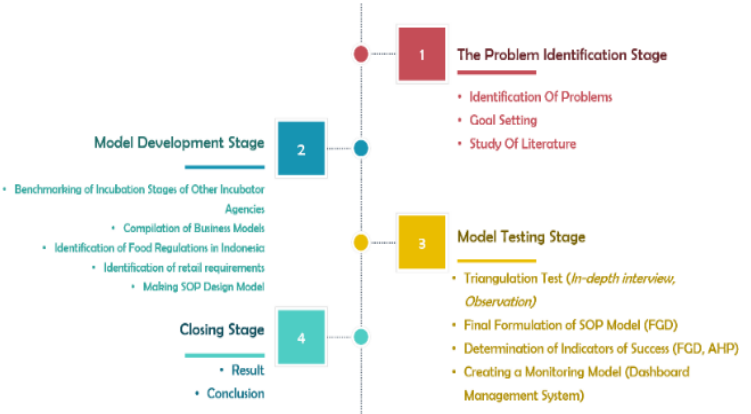

Fig. 3. Stages of Research 


\subsection{Stage 1}

At this stage the expected output is as follows: 1.) identification of the problem to be resolved; 2.) the purpose of the study is determined; 3.) Study of literature that can be a supporting theory in research.

\subsection{Stage 2}

The model development phase is the phase where the future model is expected to be formulated as an SOP. To achieve this, the steps that need to be taken are: 1. Comparative study of SOPs of other business incubator institutions; 2.) Preparation of tenant business models that are objects of observation; 3.) Identification of food regulation in Indonesia. 4.) Identification of retail requirements; 5.) Model development.

\subsection{Stage 3}

The model that has been made at the development stage so that it is valid and reliable it needs to be tested. Because this research is qualitative, the test is carried out using the triangulation method. Triangulation carried out is a method of triangulation, namely document study, interview, and observation. The results of triangulation will be input at the final agreement stage with BIT as the owner of the system. This activity is packaged with the FGD method. The expected results from the FGD in addition to obtaining the final SOP model output are also expected to obtain the weights from each variable which are indicators of success.

The weight obtained from the FGD was further processed by the AHP technique which in this study for efficiency was carried out with the Expert Choice V11 application.

\subsection{Stage 4} made.

This stage is the final stage of research where all results are presented and conclusions are

\section{Model Development \\ 4.1 Benchmarking of Incubation Stages}

There are seven business incubator institutions studied to be a comparison in making SOP models. This comparative study data was obtained from the final report of the study of technology business incubator institutions compiled by the Ministry of Research, Technology and Higher Education (2017). The seven institutions studied as a comparison of SOP incubation processes have different characteristics. From the results of the comparative study, it can be seen that at present there are no business incubators who have made SOPs to assist market access in accordance with the technology field. So that in this study cannot provide input regarding the process that can be a stage in the development of market access SOP models.

\subsection{Compilation of Business Models}

In this study a more in-depth study was conducted on BMC applications in offer-driven groups. With the aim that the business model is more comprehensive, the preparation is combined with other marketing theories such as BOS and marketing funnel. Theory of BOS is used to compile a value proposition while the funnel marketing helps improve its business model. From the studies that have been carried out, in this study three patterns of business model preparation were proposed based on the characteristics of each product. The prepared value proposition was tested on the Google search engine to determine the level of market understanding of the product. From the search results or what is well known as the Search 
Engine Result Page (SERP), you can find out what strategies can be done in preparing the business model. The first BMC pattern is aimed at products with SERP testing on the first page and the number of competitor products is small, then the next step that needs to be done is the BMC model developed by [7] Carpenter which can be seen in Figure 4. Whereas the second BMC pattern is aimed at the SERP test results obtained by the product on the first page but there are many similar products so that business competition becomes tight so that the business model preparation aims to penetrate the market by exploring key partners that can be invited to cooperate and reference to the preparation of BMC can be seen in figure 5. While the third pattern is aimed at products with SERP results not found on the first page but on the second page, the strategy that must be done is to increase awareness and reference to the preparation of BMC can be seen in Figure 6.

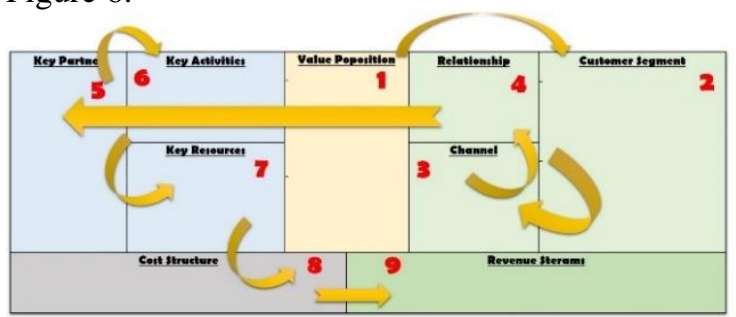

Fig. 4. $1^{\mathrm{t}}$ Pattern BMC Compilation(Carpenter, 2017)

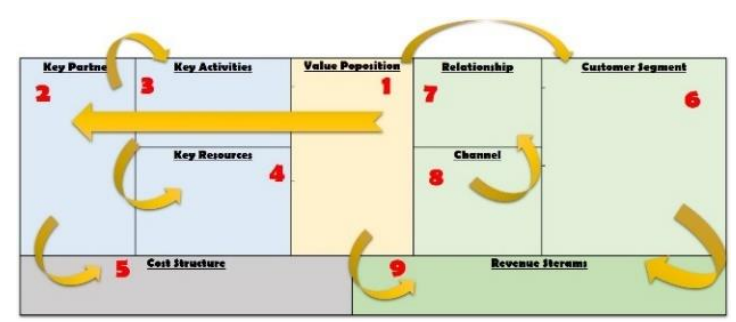

Fig. 5. $2^{\text {nd }}$ Pattern BMC Compilation (Development of the Carpenter model (2017)

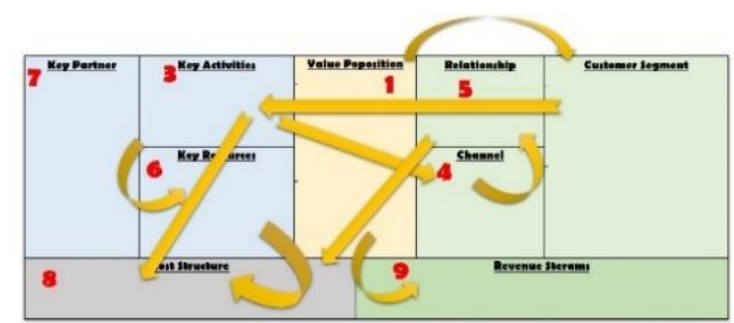

Fig. 6. $3^{\text {rd }}$ Pattern BMC Compilation (Development of the Carpenter model (2017)

And to make it easier to fill in each block then to make BMC with $1^{\text {st }}$ Pattern, $2^{\text {nd }}$ Pattern, and $3^{\text {rd }}$ Pattern by collaborating the BOS method and marketing funnel are as follows: 


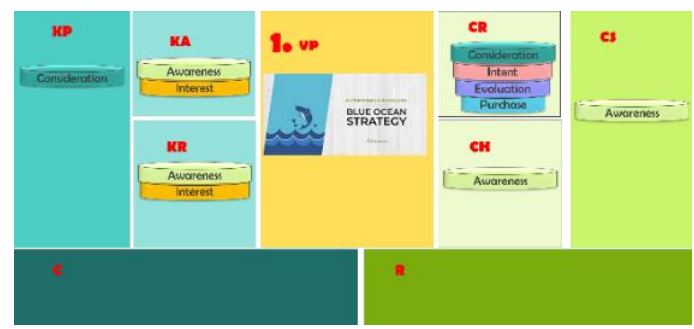

Fig. 7. BMC Compilation collaborated with BOS and Marketing Funnel

Using the references mentioned above, it was found that cassava rice products are suitable for using the first pattern of BMC, for products of spirulina sago noodles more in accordance with the 3rd BMC pattern, and BG products using the second pattern BMC reference.

\subsection{Mandatory Food Regulation in Indonesia}

From the studies that have been conducted, compulsory regulations are obtained which need to be obeyed by tenants if they want to commercialize food products as follows: a.) Comply with food, quality and nutrition security requirements, therefore, in the packaging it is necessary to display clear information, it must be true and accountable.; b.) The design used must meet ergonomic visual display rules.; c.) Have a registration number issued by BPOM if production is carried out not in a residence and PIRT for the location of residence.; d.) Optional: Halal certification issued by the MUI.

\subsection{Mandatory Retail Requirements}

This activity is carried out to determine the criteria for products that can be marketed through third parties, especially retail. Retail that is a partner in this study is retail, which is the target of tenant marketing, which has locations in the cities of Jakarta, South Tangerang and Lampung. From this study, the results of the tenants stipulated by the tenants are as follows:

Table 1. Mandatory Retail's Requirements

\begin{tabular}{|l|l|}
\hline No. & \multicolumn{1}{|c|}{ Document Name } \\
\hline 1 & $\begin{array}{l}\text { Deed of Establishment and Deed of } \\
\text { Amendment in accordance with Law No. } \\
40 \text { of } 2007 \text { concerning Limited Liability } \\
\text { Companies and Decree of the Ministry of } \\
\text { Law and Human Rights }\end{array}$ \\
\hline 2 & $\begin{array}{l}\text { Company Registration Certificate that is } \\
\text { still valid }\end{array}$ \\
\hline 3 & $\begin{array}{l}\text { Certificate of Business Domicile that is } \\
\text { still valid }\end{array}$ \\
\hline 4 & Valid Trading Business License \\
\hline 5 & $\begin{array}{l}\text { The Taxpayer Identification Number of } \\
\text { the Company and the authorized Directors }\end{array}$ \\
\hline 6 & Valid Identity Card \\
\hline 7 & $\begin{array}{l}\text { Current Account for at least the last } 3 \\
\text { months }\end{array}$ \\
\hline
\end{tabular}




\subsection{Making SOP Design Models}

The development of the SOP model has begun with the needs assessment stage so that some data can be obtained that can be used as input for the preparation of the SOP model for the food market access process which can be seen in Figure 8 where it can be explained as follows:

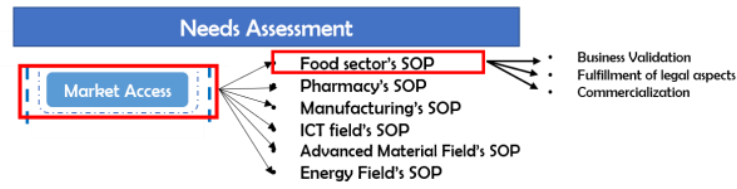

Fig. 8. Results of Needs Assessment

\subsubsection{Business Validation}

Ries[3] states that business development activities are not only carried out by planning but need to be tested from the planned concept. In the lean startup method the business model that has been compiled with the BMC method needs to be tested for reliability by applying it in real terms in the field or by Ries[3] called the Get Out Of The Building (GOOB) stage. The purpose of this activity is to find out whether the BMC has been arranged accordingly or not, if it is appropriate, then the tenant's business can be further developed but if it is not right it needs to be repaired or the worst possibility must be ended. By adopting GOOB on lean startup[3], the procedures for implementing this concept are as follows: 1.) Prepare BMC.; 2.) Determine the location of the business validation implementation in accordance with the business model that has been prepared.; 3.) Determine the target of success.; 4.) Prepare a number of questions that can be used to evaluate the entire business.; 5.) Analyse the implementation of business validation activities

\subsubsection{Commercialization}

In the commercialization activity itself consists of 3 stages, namely the stage of fulfilling the legal aspects, the promotion stage, and the sales stage.

\section{Model Testing}

\subsection{Triangulation Testing}

\subsubsection{Triangulation testing on experts (in-depth interview)}

The triangulation technique used in this study is a type of triangulation method. The results of the SOP resulting from the development of the literature study tested the data validity and validity of the two schemes tested on the expert team and tested on the actual ecosystem. Model testing with interviews is carried out involving one marketing expert and two business experts and the results obtained are as follows: a.) For time efficiency and effectiveness of commercialization, the fulfilment of legality aspects in the marketing access stage should only be in the form of document collection rather than providing assistance for certification / legality of business entities.; b.) Taking into account the demands of the modern retail industry that demands professional relations, in addition to the legality aspect, BIT must provide additional criteria for tenants, namely sustainable production so that they can meet demands on delivery deadlines, prices offered and product availability.; c.) The success of the validation stage of the tenant business model is largely determined by the level of understanding of the business model planned by the tenant.; d.) In preparing the business model the tenant also needs to be considered: 1.) Market development trends.; 2.) Analysis of business competition on similar products to determine the positioning, branding, accuracy of pricing policies, and packaging. 


\subsubsection{Triangulation testing on real ecosystem (observation)}

Designing the SOP model that has been tested to experts, the model developed is tested again by applying the model to the actual ecosystem from the commercialization stage. The location of the testing consists of small retail stores, modern retail stores, and internet-based stores according to the business model that has been developed. From the three business models, it can be seen that the channels of product marketing are modern retail stores, special small retail stores (organic and herbal), and pharmacies, therefore the model testing activities are carried out at that place. From the testing phase of the SOP model by means of observations obtained the following results: a.) the efficiency of time and the achievement of the objectives of commercialization, it is better before the access stage of marketing for the tenant has the legality that has become a condition set by modern retailers.; b.) To overcome the costs of benefits set by modern retailers, at the price fixing tenants must at least have a profit margin of at least more than $40 \%$ of the cost of production.; c.) Before the commercialization activities are carried out, tenants need to determine the marketing strategy to be carried out whether or not they are brand holders.; d.) To optimize the business development process, for tenants who already have a large number of markets (BG cases), the tenants need to have a process of escalating the production process.

\subsection{Improvement of the Design and Development of the SOP Model and Monitoring Mode}

\subsubsection{Audience with the BIT Expert Team (FGD)}

The FGD activities are planned to be attended by all entities from BIT as system owners who will later become implementers of the models designed by researchers. The FGD results are as follows: 1.) Need some adjustments including the business validation stage, and the addition of the process of signing a memorandum of understanding; 2.) The adjustments that need to be made in the SOP of the Business Model Compilation Assistance are: a.) Kasie FUT as an Incubator Manager has the responsibility of making reports with the help of the facilitator and; b) the role of the Head of BIT in the preparation of business models is only involved in giving recommendations.; 3.) Determination of weight of criteria and indicators of success (KPI) that shown below:

Table 2: Determination of Criterion and Its Weight

\begin{tabular}{|l|l|l|}
\hline No. & Criterion & Weight \\
\hline 1 & Validation & 0,35 \\
\hline 2 & Commercialization & 0,65 \\
\hline
\end{tabular}

Table 3: Determination of Sub Criterion and Its Weight

\begin{tabular}{|l|l|lr|}
\hline No. & Sub Criterion & Weight \\
\hline 1 & Business Model & $30 \% \quad$ of \\
& Making & 0,35 & \\
\hline 2 & Determining the & $20 \% \quad$ of \\
& Location of Validation & 0,35 & \\
\hline 3 & Validation & $50 \% \quad$ of \\
& implementation & 0,35 & \\
\hline 4 & Fulfilment of Legality & $\begin{array}{l}7,69 \% \text { of } \\
\end{array}$ & 0,65 \\
\hline
\end{tabular}




\begin{tabular}{|l|l|l|}
\hline 5 & Promotion & $23,08 \%$ of \\
& & 0,65 \\
\hline 6 & Sales Transaction & $69,23 \%$ of \\
& & 0,65 \\
\hline
\end{tabular}

And the KPI for the system are:

Table 4: Determination of KPI

\begin{tabular}{|c|c|c|c|}
\hline No & Criterion & Sub Criterion & KPI \\
\hline \multirow[t]{3}{*}{1} & \multirow[t]{3}{*}{$\begin{array}{l}\text { Validatio } \\
\mathrm{n}\end{array}$} & $\begin{array}{l}\text { Business Model } \\
\text { Making }\end{array}$ & $\begin{array}{l}\text { Business } \\
\text { Model }\end{array}$ \\
\hline & & $\begin{array}{l}\text { Determining the } \\
\text { Location } \\
\text { Validation }\end{array}$ & $\begin{array}{l}\text { Alternative } \\
\text { Location }\end{array}$ \\
\hline & & $\begin{array}{l}\text { Validation } \\
\text { implementation }\end{array}$ & $\begin{array}{l}\text { Validation } \\
\text { Report }\end{array}$ \\
\hline \multirow[t]{7}{*}{2.} & \multirow{7}{*}{$\begin{array}{l}\text { Commer } \\
\text { cializatio } \\
\mathrm{n}\end{array}$} & \multirow[t]{7}{*}{$\begin{array}{l}\text { Fulfilment of } \\
\text { Legality Aspects }\end{array}$} & $\begin{array}{l}\text { Deed of } \\
\text { company }\end{array}$ \\
\hline & & & $\begin{array}{l}\text { Company } \\
\text { Registration } \\
\text { Certificate } \\
\text { (TDP) that is } \\
\text { still valid }\end{array}$ \\
\hline & & & $\begin{array}{l}\text { Certificate of } \\
\text { Business } \\
\text { Domicile } \\
\text { that is still } \\
\text { valid }\end{array}$ \\
\hline & & & $\begin{array}{l}\text { Valid } \\
\text { Trading } \\
\text { Business } \\
\text { License } \\
\text { (SIUP) }\end{array}$ \\
\hline & & & $\begin{array}{l}\text { The } \\
\text { Taxpayer } \\
\text { Identificatio } \\
n \text { Number } \\
\text { (NPWP) of } \\
\text { the } \\
\text { Company } \\
\text { and the } \\
\text { authorized } \\
\text { Directors }\end{array}$ \\
\hline & & & $\begin{array}{l}\text { Valid } \\
\text { Identity Card } \\
(\mathrm{KTP}) \\
\end{array}$ \\
\hline & & & $\begin{array}{l}\text { Current } \\
\text { Account for }\end{array}$ \\
\hline
\end{tabular}




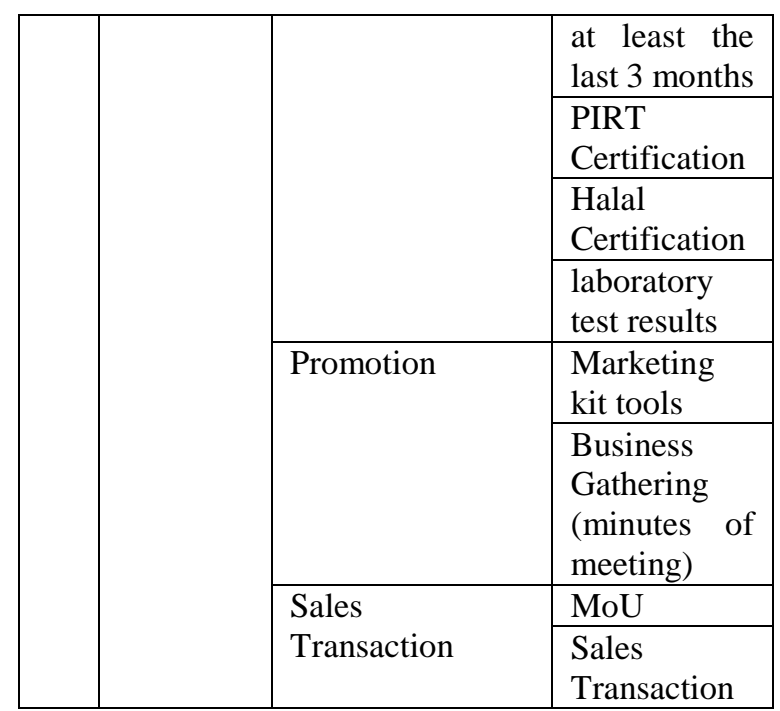

\subsubsection{Determination of Weight Using Expert Choice V11}

The weight value that has been obtained from the FGD is processed by the AHP method and for time efficiency, Expert Choice V11 software is used in this study. The final results of the weight values that have been processed are as follows:

Table 5: Calculation Results Weight with Expert Choice V11

\begin{tabular}{|l|l|l|l|l|}
\hline No & Criterion & Weight & Sub Criterion & Weight \\
\hline 1 & Validation & 0.33 & $\begin{array}{l}\text { Business } \\
\text { Model Making }\end{array}$ & 0,098 \\
\cline { 4 - 5 } & & $\begin{array}{l}\text { Determining } \\
\text { the Location of } \\
\text { Validation }\end{array}$ & 0,054 \\
\cline { 3 - 5 } & & $\begin{array}{l}\text { Validation } \\
\text { implementation }\end{array}$ & 0,178 \\
\hline 2 & $\begin{array}{l}\text { Commercial- } \\
\text { ization }\end{array}$ & 0.67 & $\begin{array}{l}\text { Fulfilment of } \\
\text { Legality } \\
\text { Aspects }\end{array}$ & 0,05 \\
\cline { 3 - 5 } & & 1 & Promotion & 0,15 \\
\cline { 3 - 5 } & & $\begin{array}{l}\text { Sales } \\
\text { Transaction }\end{array}$ & 0,46 \\
\hline & TOTAL & 1 & TOTAL & 1 \\
\hline
\end{tabular}

\section{Result}

From the picture below, it can be seen that there are three boxes with different colours when compared to the others, it is done to show the improvements that have been made.

The first revise (point 8.3) is the flow of decisions regarding product development improvement decisions that are permitted to be carried out in marketing access activities are minor improvements while for validation results that require major improvement in product development it is necessary to conduct monitoring and evaluation activities which will certainly 
a bad value for the development of tenant businesses. From the results of the FGD, it was agreed that minor improvements that could be made include: a.) Colour adjustment of packaging design.; b.) Adjustment of product information on packaging.; c.) Adjusting the volume of products sold.

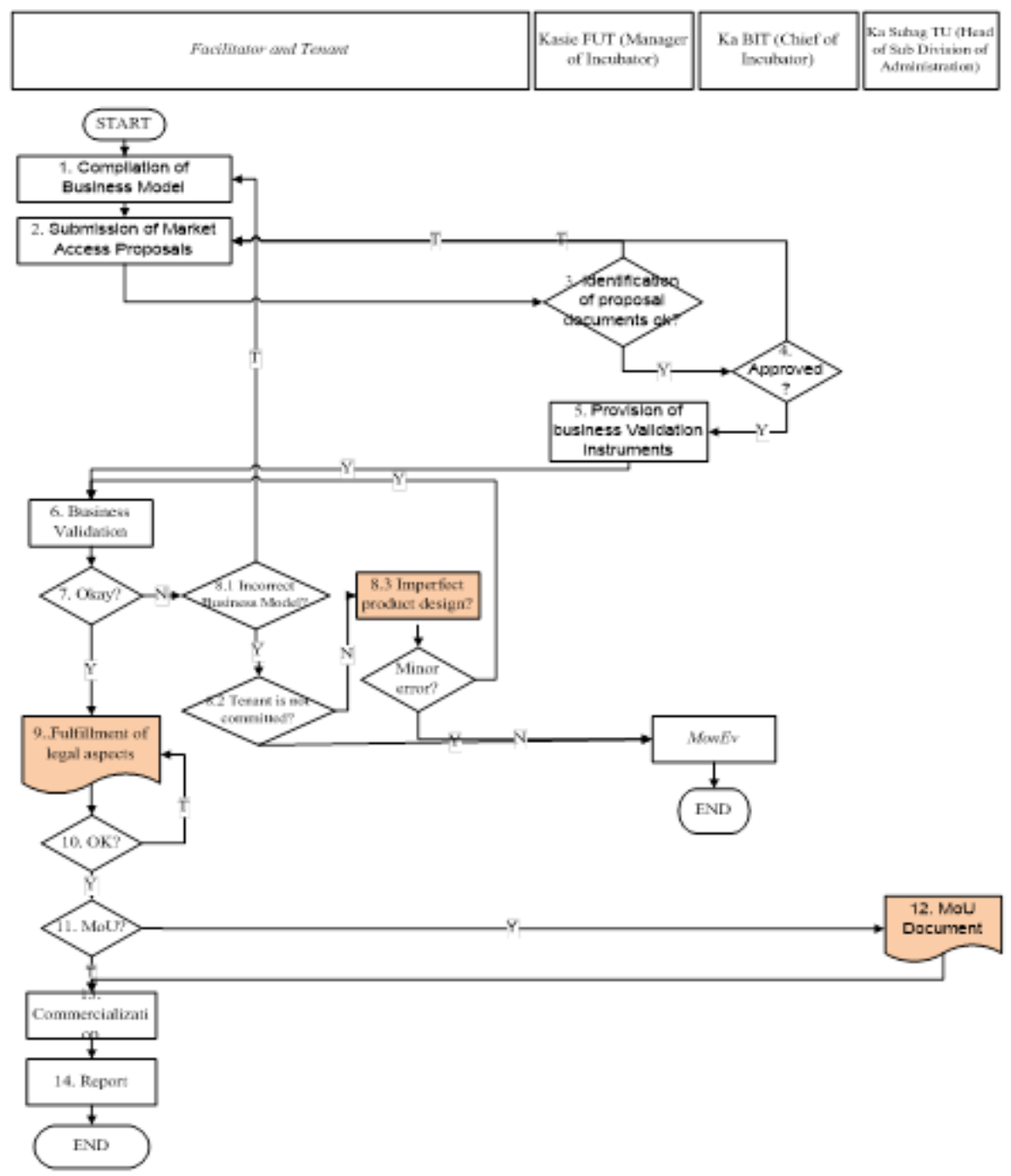

Fig.9. Final Model of Market Access SOP

Then for the second adjustment is the stage of fulfilling the original legality aspect is a process changed by collecting documents because the main output at this stage is only to collectively document the legality aspects of the business and products. Whereas for the third adjustment is the addition of the process of making cooperation agreement documents because some parties make this document a basis for cooperation. In the activity of signing the cooperation agreement, it will involve the Head of the Administration Section. 


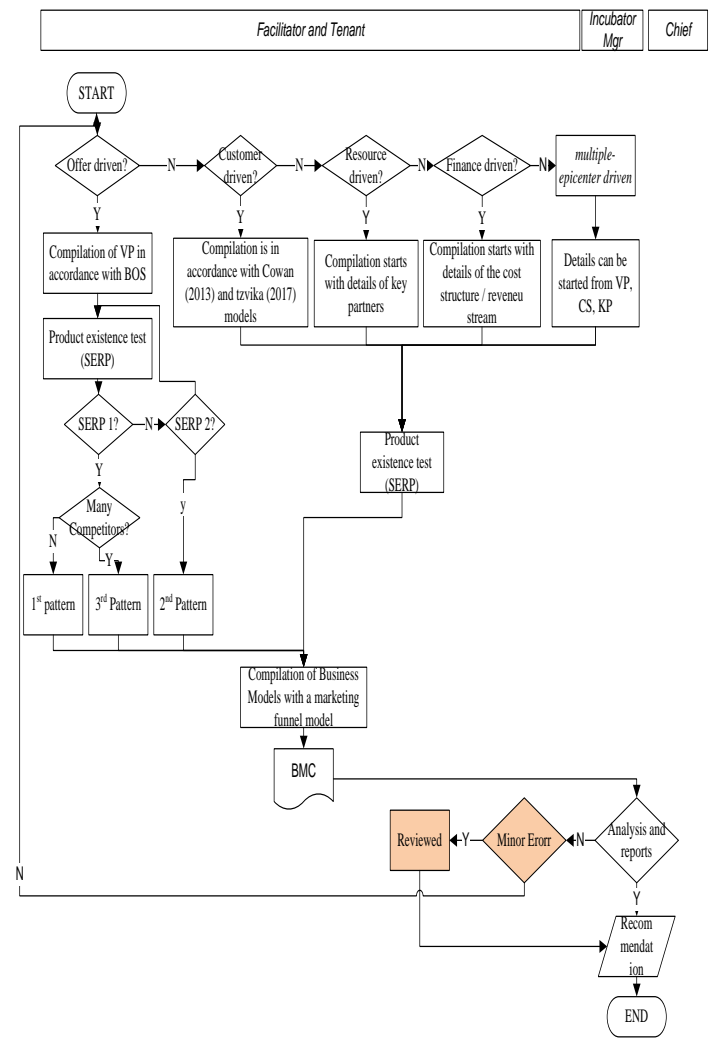

Figure 10: Final Model of Assistance in Preparing Tenant Business Models

As for adjusting the SOP for the Tenant Business Model Compilation, shown in the figure below, there are some improvements. Adjustment by adding consideration to the decision if it is necessary to adjust the business model to be carried out by the tenant if the business model changes on the advice and input from the incubator manager (Head of FUT) and / or Head of BIT if it is minor then can be carried out immediately if major changes are define business models, adjustments must be made starting from the beginning.

From the results above, a monitoring model was created which in its adoption adopted the management system dashboard concept. In the development of this monitoring model the data entered is: a.) Flow of activities.; b.) Indicator of success.; c.) Weight of criteria and sub criteria. This monitoring design was developed with due regard to the design of the official BIT website (http://bit.bppt.go.id/) because in the future it will be used as the official media from BIT to monitor the progress of the tenant incubation process. And here are the results of developing a monitoring model: 


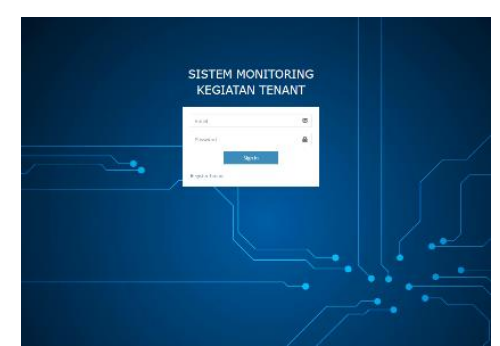

Fig. 11. Final Monitoring Model (Login Page)

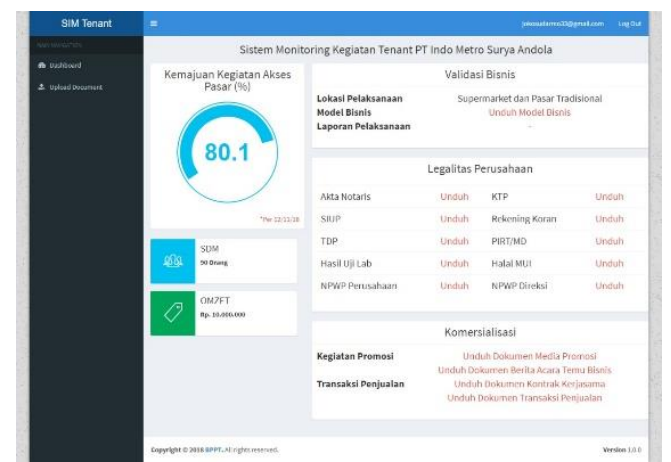

Fig. 12. Final Monitoring Model (Dashboard Management System)

\section{Conclusions}

The application of the concept of lean startup as a theoretical foundation in the preparation of the incubation curriculum in BIT can be applied well but needs some adjustments, especially in determining the indicators of success. In testing the model, the results show that it is necessary to adjust the Market Access SOP model and the SOP for Business Model Compilation. 2 In testing the model, it was found that the success of market access activities was very dependent on the commitment of the tenants and the completeness of the legal documents that they had, so it is necessary to adjust the Market Access SOP model.

\section{Acknowledgements}

This research is supported financially by Lembaga Pengelola Dana Pendidikan (LPDP) from Kementerian Keuangan Republik Indonesia.

\section{References}

[1] M. H. Alomari, E. A. Awada, A. Samaha, and K. Alkamha, "Wavelet-Based Feature Extraction for the Analysis of EEG Signals Associated with Imagined Fists and Feet Movements," vol. 7, no. 2, pp. 8-12, 2014.

[2] A. S. P. Cakrasiwi, W. Sutopo, and A. Widiyanto, "Evaluasi Keberhasilan Strategi Bisnis Komersialisasi Teknologi Tenant (Studi Kasus: Tenant BIT - BPPT)," in 
Seminar Nasional Industrial Engineering Conference (IDEC) 2015, 218 - 224, 2015.

[3] A. Ries and L. Ries, "The 22 Immutable Laws of Branding, Symphonya. Emerging Issue." 2011.

[4] S. Blank, Why the Lean Start-up Changes Everything. Harvard Business Review, 2013.

[5] M. D. Nirwan and W. Dhewanto, "Barriers in Implementing the Lean Startup Methodology in Indonesia - Case Study of B2B," Startup. Procedia - Soc. Behav. Sci., vol. 169, no. 23 - 30, 2014.

[6] A. Osterwalder and Y. Pigneur, Business Model Generation. New Jersey: John Wiley \& Sons, 2010.

[7] J. Carpenter, "Lucidchart's Quick and Dirty Guide to the Business Model Canvas. Lucidchart. Available.” 2017. 